\title{
都市河川における雨天時污濁負荷の実態と 水質・底質への影響 \\ POLLUTANT LOAD IN RAINY WEATHER AND ITS INFLUENCE ON WATER AND BENTHIC ENVIRONMENT IN URBAN RIVERS
}

\author{
中谷祐介 1 ・今福大智 2 ・根井大輝 2 -西田修三 3 \\ Yusuke NAKATANI, Daichi IMAFUKU, Daiki NEI and Shuzo NISHIDA \\ 1正会員 博 (工） 大阪大学大学院助教 工学研究科地球総合工学専攻（干565-0871 吹田市山田丘2-1） \\ 2学生会員 学 (工) 大阪大学大学院 工学研究科地球総合工学専攻（†565-0871 吹田市山田丘2-1) \\ 3 正会員 工博 大阪大学大学院教授 工学研究科地球総合工学専攻（干565-0871 吹田市山田丘2-1）
}

To quantify pollutant inflow load in wet weather and elucidate its influence on water and benthic quality in urban rivers, field surveys and laboratory experiment were conducted. As a result, water qualities of drainage water from the CSO outlets and freeway outfalls showed significant fluctuations according to precipitation variation. The pollutant inflow load in wet weather had a minor impact on the mass balance in the waters. Moreover, the results of stable isotope ratio analysis indicated that the organic matter from CSO outlets and freeway outfalls did not constitute a large portion of sediments in the rivers.

Key Words : combined sewer overflow, freeway drainage, pollutant load, water quality, urban river

\section{1.はじめに}

古くより社会基盤整備が進められた都市域では，合流 式下水道が採用されている場合が多い，合流式下水道は 浸水対策と水洗化の普及を同時に行えることに加え，雨 水と污水を単一管渠で排除するために，分流式下水道に 比べて整備コストを抑えることができるという利点があ る. しかし, 雨天時には大量の雨水とともに, 処理場で 処理しきれなくなった污水が未処理のまま公共用水域一 排出される。これを合流式下水道越流水 (Combined Sewer Overflow，以下CSOと記す） と呼び，公衆衛生上, 水質保全上，景観上の問題を引き起こすことが指摘され ている.わが国では2000年頃からCSO問題への対策が始 められ，合流式下水道緊急改善計画に従った様々な事業 が各自治体において現在着実に進められている.

CSOによる污濁負荷については，水域環境へ甚大な影 響を及ぼしていることが懸念される。しかし，現地実測 が難しいこともあり，環境基準項目に指定されている $\mathrm{COD}, \mathrm{BOD}, \mathrm{SS}$, 細菌類に着目した調査例 ${ }^{1), 2}$ (は存在す るものの，水環境の解析に重要な形態別の栄養塩類に関 するデータの蓄積(少ない(3),4)，そのため，CSOが水域環 境へ及ぼす影響やその流出制御による水質改善効果につ
いて，定量的な知見は未だ限られているのが現状である. 本研究では，大阪都市部を流れる東横堀川と道頓堀川 を対象に，雨天時に流入する污濁負荷の実態調査を実施 するとともに，河川環境への影響について解析を行う.

\section{2. 方法}

\section{(1) 研究対象領域}

研究対象領域を図-1に示寸。大阪都心部を流れる東横 堀川と道頓堀川は，多量の污濁負荷の流入により1970年 頃にはBOD值が20～30mg/Lと極めて劣悪な水質環境に あった. その後, 様々な施策により水質は大幅に改善さ れたものの，現在もほぼ全域にわたつて貧酸素水塊が発 生しており，さらなる水質改善が求められている.

東横堀川は淀川水系の下流部に位置し，南北に流れる 全長約 $3 \mathrm{~km}$, 川幅約 $20 \mathrm{~m}$ の河川である. 南端からは道頓 堀川と名を変え, 約 $2.5 \mathrm{~km}$ 西流した後, 下流端で木津川 に合流する. 道頓堀川の河川幅はSta.3付近を境に変化し， 西部区間が約 $50 \mathrm{~m}$ ，東部区間が約 $30 \mathrm{~m}$ とっている.

東横堀川と道頓堀川はともに人工的に開削されてでき た運河であり，上下流端は水門によって普段は閉鎖され ている. 水門の役割としては，高潮の防御，水位の制御， 


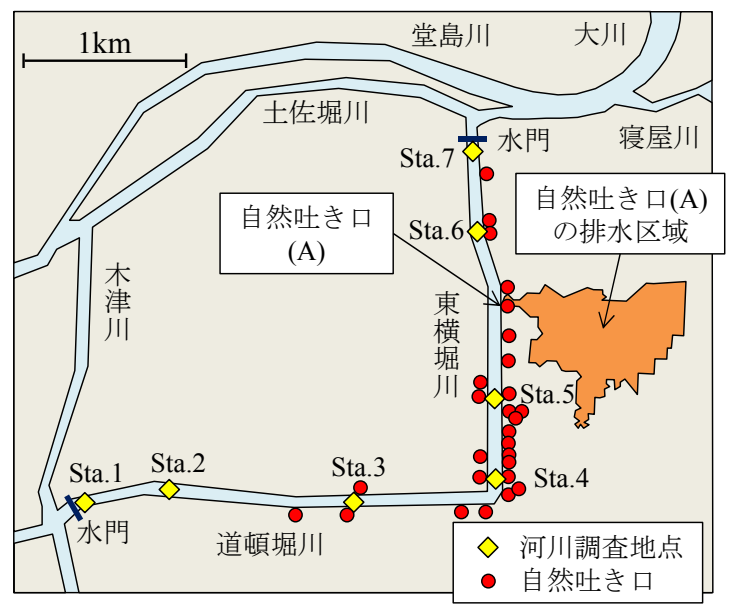

図-1 研究対象領域

船舶を航行させるための閘門機能に加え，感潮域である ことを利用した水質浄化運転機能が挙げられる. 寸なわ ち，上げ潮時には東横堀川水門を開けて比較的清浄な大 川の河川水を取り入れる一方で，下げ潮時には東横堀川 水門を閉じて污濁した寝屋川の河川水が流入しないよう にするとともに，道頓堀川水門を開けて下流に排水する ことで，河川の水質浄化を図っている. このため，当水 域では水の流入出が東横堀川から道頓堀川への一方向か つ一時的にしか発生せず，ほとんどの期間は停滞水域と なっている，また，東横堀川では河川を覆うように高速 道路の高架橋が通っており, 雨天時には高速道路排水が 河道部一直接流入している.

当水域では，図-1に示す28ケ所の自然吐き口において $\mathrm{CSO}$ が頻繁に発生している. 現在, 平成の太閤下水 (北 浜逢阪貯留管）と称されるCSOの一時貯留管の建設が進 められており，これによって10年確率降雨に対しても CSOが発生しなくなるとされている. しかし，吉田 ${ }^{5} に$ より数回にわたるCSOの観測および負荷量の算定は行わ れているものの，排出先である東横堀川・道頓堀川の河 川環境への影響に着目した調査解析はなされていない.

\section{（2）現地調査}

河川に流入する雨天時負荷の実態と河川環境への影響 を明らかにするために, CSO調査, 高速道路排水調查, 河川水質・底質調查を実施した。調查は2013年10月下旬 より開始し現在も継続しているが，ここでは2014年8月 中旬までに得られたデータを使用する.

上述の通り, 東横堀川と道頓堀川には合計28ヶ所の自 然吐き口が存在するが，今回はそのうち集水面積が約 51ha と最も大きい自然吐き口A（図-1参照）において $\mathrm{CSO}$ 調查を実施した。調査は吐き口より約 $30 \mathrm{~m}$ 下水管路 上流に位置する雨水吐き室において行った．調查を実施 した雨水吐き室の構造を図-2に示寸. 雨水が流入し, 雨 水吐き室内の水位が越流堰高さを超えるとCSOが発生す る. 採水には自動採水器（ポータブル型900MAX,

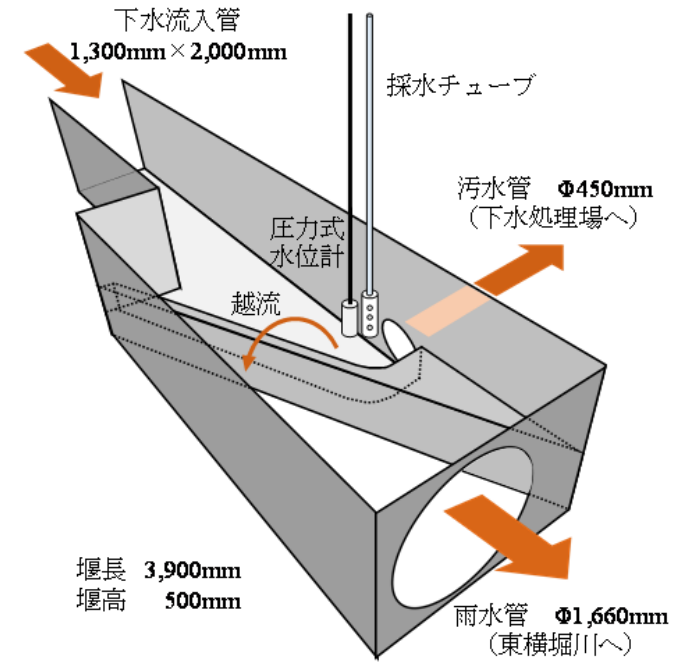

図-2＼cjkstart雨水吐き室の構造

HACH製）を使用し，雨水吐き室上部のマンホール蓋に 機器を吊り下げて設置した。また，圧力式水位計

(Compact-TD，JFEアドバンテック製）を用いて管内水 位をモニタリングし, 水位が越流堰の高さに到達する少 し前から採水が開始されるように機器を設定した。

河川水質調査はCSOが発生した降雨を対象に，図-1に 示寸Sta.1からSta.7を巡回して実施した. 多項目水質計

(AAQ-1183，JFEアドバンテック製）とDO計（Quanta G，Hydrolab製）を用いて橋上から流心で水温，電導度， 濁度，Chl.-a，DOの鉛直分布を測定するとともに，表層 水を採取し水質分析に供した. Sta.4では河川調査と並行 して, 高速道路高架橋の橋脚排水口から流出する高速道 路排水をバケツで採取した.

水質分析項目はSS, COD, および形態別の窒素, リ ン，ケイ素，炭素とした. 懸濁態成分については全成分 と全溶存態成分との差より，溶存有機態成分については 全溶存態成分と溶存無機態成分との差より求めた．栄養 塩類, 有機炭素, $\mathrm{COD}$ の分析にはそれぞれAACS-V

(BLTEC製），TOC-V（島津製作所製），吸光光度計 DR2400（HACH製）を使用した．分析方法はそれぞれ 連続流れ分析法, 酸性化 - 通気処理法, 吸光光度 - 過又

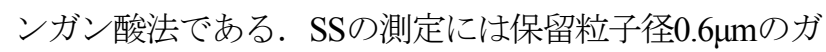
ラス繊維濾紙（GS-25, ADVANTEC製）を使用した。 また，2014年3月13日に採取したCSO試料と高速道路排 水試料については, 試料水中に含まれる懸濁物質の炭 素・窒素安定同位体比の分析を行った. 分析には質量分 析計（DELTA V，Thermo Fisher Scientific製）を使用した。 河川底質調査は2013年10月17日と2014年6月25日に実 施した. Sta.1からSta.7の間に架かる橋上から, 河道中央 においてエクマンバージ型採泥器（HOGA製）で表層泥 を採取し，冷暗条件下で実験室に持ち帰った。試料は $2 \mathrm{~mm}$ ふるいにかけた後, 強熱減量 $\left(600^{\circ} \mathrm{C}\right.$ で 2 時間強熱 $)$ を測定するとともに, 乾燥粉砕・脱炭酸処理後に炭素・ 窒素安定同位体比の分析に供した。 


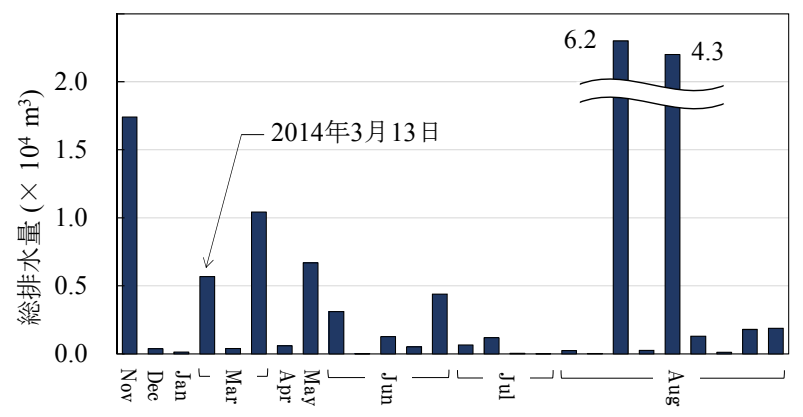

図-3＼cjkstart各降雨イベントにおけるCSO総排水量

\section{（3）水理模型実験}

雨水吐き室では水位が堰高を超えるとCSOが発生する が，その越流量を現地で計測することは難しい，堰越流 量の算定には種々の公式が提案されているが，雨水吐き 室の形状が複雑な場合や，堰下流側の水深が一定以上の 場合には公式を適用することができない，そこで，CSO 越流量を求めるために，図-2に示した雨水吐き室の縮尺 模型（縮尺比6/100）を作成し，水理実験を行った。模 型材料には透明アクリル板および塩ビ管を使用した．上 流からの流入水量を段階的に変化させて越流水深H 流量Qを計測し，フルード相似則に従って実スケールの $\mathrm{H}-\mathrm{Q}$ 関係式を構築した.

\section{3. 結果と考察}

\section{（1）雨天時排水の水質特性}

図-3に調査期間中に発生したイベント毎のCSO総排水 量を示す，期間中にCSOは26回発生したが，ここでは一 例として, CSO発生前後を含めて詳細なデータが得られ た2014年3月13日の調查結果を図-4に示す．3月13日の $\mathrm{CSO}$ は総排水量の規模でみると上位6番目に当たり, 総 降水量は $36.5 \mathrm{~mm}$, 先行晴天日数は 3 日であった. 1:30頃 から概ね $0.5 \mathrm{~mm} / 10 \mathrm{~min} の$ 弱雨が継続した後，14:40〜 15:30に $2 \mathrm{~mm} / 10 \mathrm{~min}$ 以上の比較的強い降雨が生じ，ほぼ 同時間帯にCSOの発生が確認された。

多くの溶存態成分については，降雨強度が増加するに つれて濃度が低下寸る傾向がみられたが，これは管内に 路面排水が流入したことにより, 下水濃度が希勫された

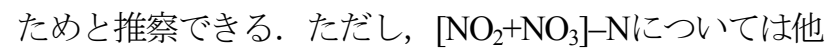
の溶存態成分とは異なり，降雨が強まった時間帯に若干 の濃度上昇がみられたが，これは下水に比べて路面排水 の濃度が高かったためと考えられる。また，16:10前後 にはDON濃度の上昇がみられたが，この原因について は今回得られたデータからは特定に至らなかった。

一方，眯濁態成分（PN，PP，POC）について着目寸 ると，14:30から15:00には管内水位が上昇するにつれて 濃度が上昇しており，下水管内または路面上の堆積物が 流量の増加に伴って徐々に掃流されたものと推察される。
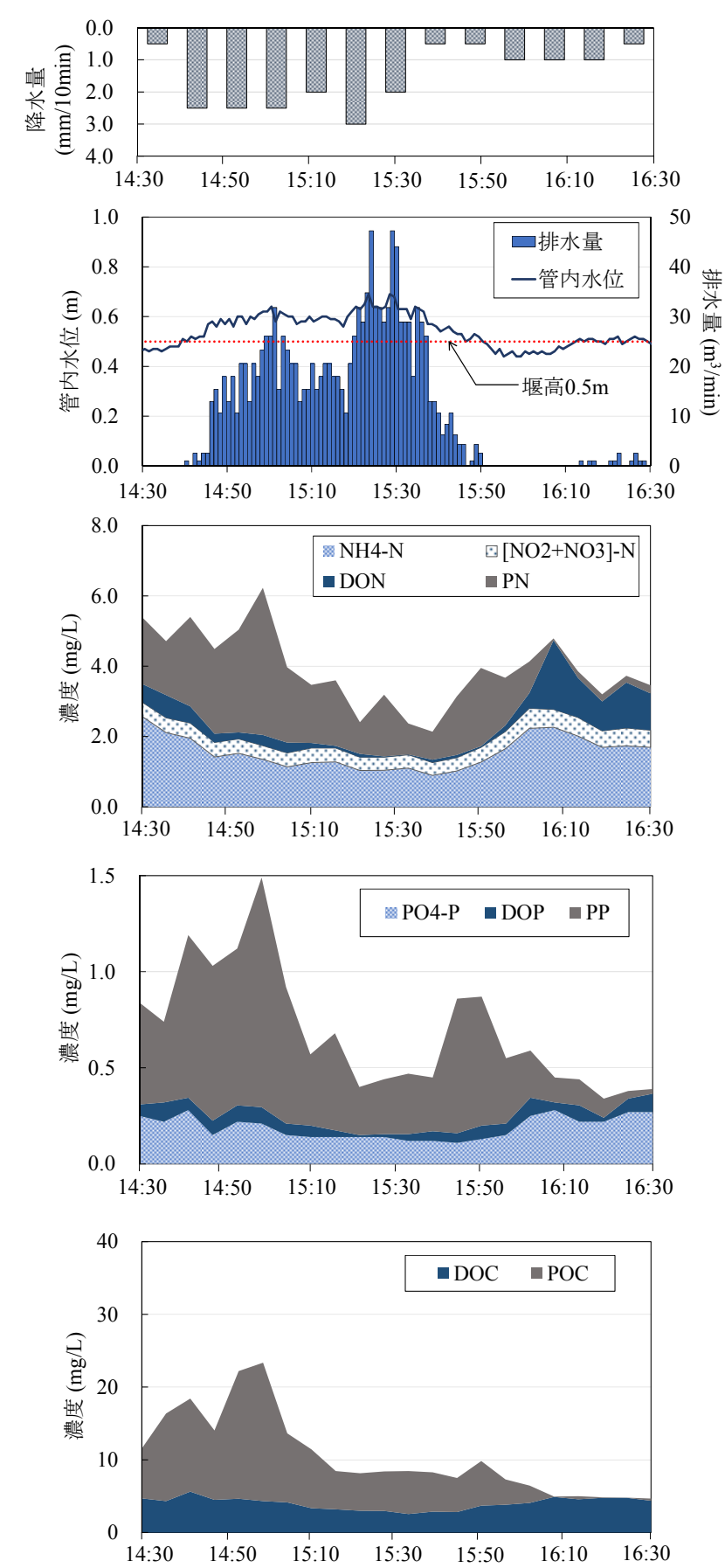

図-4 降水量とCSO排水量 · 水質の変動

その後水位は一旦低下寸るが，15:20から15:40には再び 上昇し, 当降雨イベント内での最大值を示した. しかし, この際には懸濁態成分の濃度上昇は伴わなかったことか ら, 堆積物の多くは15:00前後の一度目の流量ピーク時 までにほぼ掃流されたと考えられる，なお，水位が低下 した15:50前後にも懸濁態成分の濃度上昇がみられたが, この原因については今回得たデータからは推測できな かった. その後, 䀣濁態物質の濃度は徐々に低下し, 降 雨終了時には極めて低濃度を示した。

高速道路排水調查の結果を図-5に示寸．排水は9:00頃 より開始し，その後は降雨終了時まで継続的に発生した. 

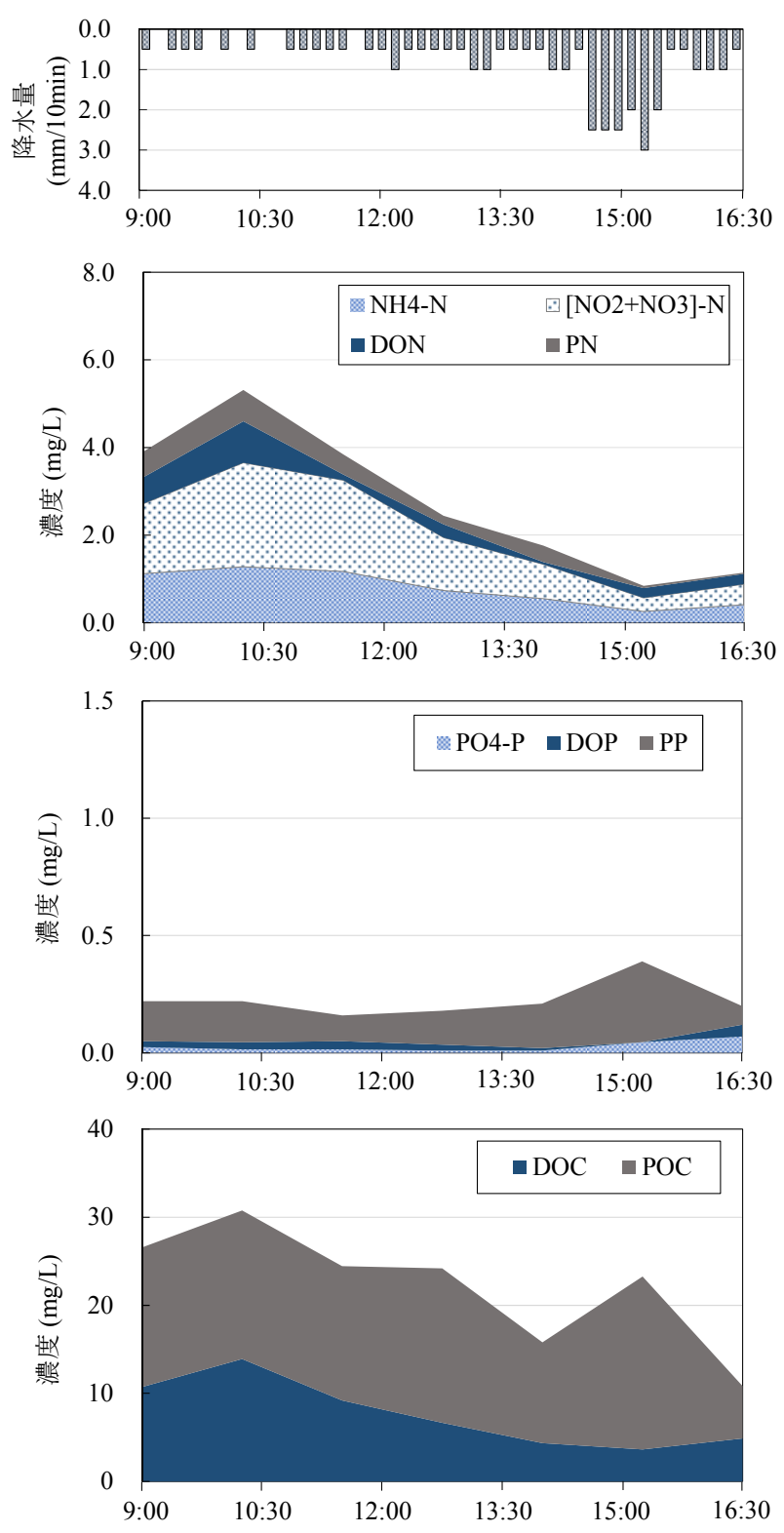

図-5 降水量と高速道路排水水質の変動

弱雨が続いた14:00頃までの濃度変動に着目すると，窒 素と炭素については10:00頃に一度上昇した後に徐々に 低下したが，リンについては大きな変化は生じなかった 15:00前後に降雨強度が高くなると，リンと炭素につい ては懸濁態成分の濃度上昇が生じているが，これは路面 堆積物が掃流された影響が現れたものと考えられる.リ ンと炭素については全成分の 40 90\%を懸濁態成分が占 めていた一方で，窒素については常に $75 \%$ 以上を溶存態 成分が占めていた。 なお，同じく高速道路排水を対象と した新矢ら $\left.{ }^{6}\right)$ の調查では，流出開始から30分以内に極め て高濃度の懸濁態物質（TOCでは最大約 $600 \mathrm{mg} / \mathrm{L} ）$ の流 出が報告されているが，今回の調査では確認されなかっ た. 今回の調査では採水を約1時間間隔で行ったため, ファーストフラッシュによる濃度変動を捉えられていな い可能性も否定できない.

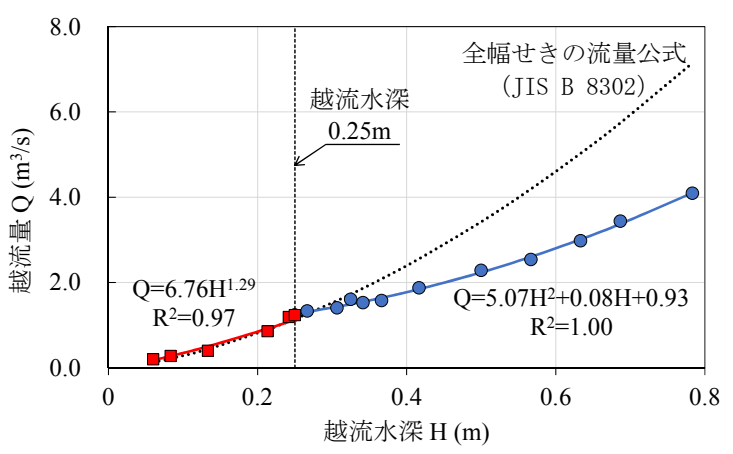

図-6＼cjkstart越流水深と越流量の関係

表-1 河川水中の存在量と流入負荷量の比較 （鍵括弧内はaに対するb，cの割合）

\begin{tabular}{|c|c|c|c|c|}
\hline \multirow{2}{*}{ 項目 } & \multirow{2}{*}{ 水量 $\left(\mathrm{m}^{3}\right)$} & \multicolumn{3}{|c|}{ 物質量 (kg) } \\
\hline & & T-N & T-P & TOC \\
\hline $\begin{array}{c}\text { a) 負荷流入前における } \\
\text { 河川水中の存在量 }\end{array}$ & $4.46 \times 10^{5}$ & $1.41 \times 10^{3}$ & 72.6 & $1.16 \times 10^{3}$ \\
\hline b) $\mathrm{CSO}$ & $5.67 \times 10^{3}[1.3 \%]$ & $19.0[1.4 \%]$ & $3.92[5.4 \%]$ & $59.9[5.1 \%]$ \\
\hline c) 高速道路排水 & $1.71 \times 10^{3}[0.4 \%]$ & $3.16[0.2 \%]$ & $0.45[0.6 \%]$ & $35.0[3.0 \%]$ \\
\hline
\end{tabular}

\section{（2）雨天時負荷の定量的評価}

水理実験より得られた $\mathrm{H}-\mathrm{Q}$ 曲線を図-6に示す．図中に はJIS B 8302に採用されている全幅せきの流量公式も併 載している. $\mathrm{H}=0.25 \mathrm{~m}$ を境に $\mathrm{H}-\mathrm{Q}$ 関係は変化し, $\mathrm{H} \leqq$ $0.25 \mathrm{~m}$ では指数関数， $\mathrm{H}>0.25 \mathrm{~m}$ では二次関数でそれぞれ 表現可能であった. $\mathrm{H}>0.25 \mathrm{~m}$ では実験より得られた関 係と流量公式に大きな差異が生じたが，これはH> $0.25 \mathrm{~m}$ では越流堰下流側の水位が上昇し, 越流部の流れ に影響を及ぼしたためと考えられる。

調査・実験結果を基に，降雨前の河川水中に存在寸る 物質量と雨天時負荷量との比較を行った. 河川水中の存 在量は, 河川水の水量と水質濃度の積より求めた. 具体 的には，河道部を流下方向に $50 \mathrm{~m}$ 間隔に分割し，各区間 について流表面積と水深の積として河川水量を算定する とともに，2014年3月12日晴天時調査で得られたSta.1〜 Sta.7の各地点の水質濃度を線形補間することで各区間の 水質濃度を推定した．また，全CSO吐き口からの総負荷 量は，自然吐き口Aにおける排水量に全吐き口との集水 面積比を乗じて求めた総排水量に, 自然吐き口Aで採取 した試料水の時々刻々の水質濃度を乗じることによって 算定した. 高速道路からの総負荷量は, 東横堀川上部の 路面面積と降水量, 路面流出係数 $(=0.83)^{7)}$ の積より 求めた総排水量に, 調査で得られた排水水質を時間方向 に線形補間して求めた水質濃度を乗じて算定した。

算定結果を表-1に示寸. 負荷流入前の河川水中存在量 に比べると, 雨天時負荷量はいずれの水質項目について も $10 \%$ 以下にしか相当せず, 特に高速道路排水によるT$\mathrm{P}$ と $\mathrm{T}-\mathrm{N}$ の負荷量はともに $1 \%$ 以下極めて小さい. この ことから，2014年3月13日に発生した中規模の降雨イベ ントによる雨天時負荷が，河道部の物質収支に及ぼす影 

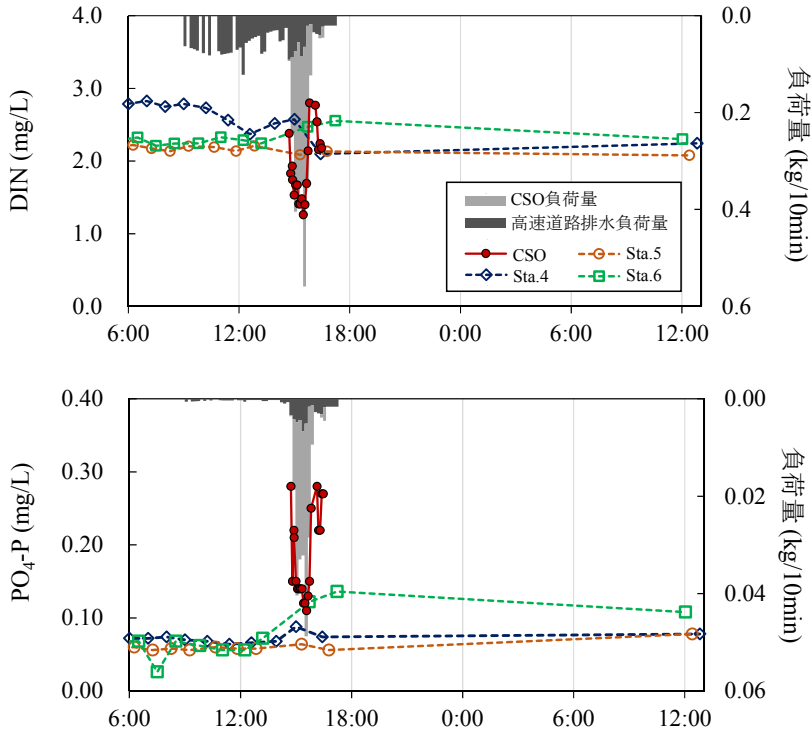

図-7 河川水質と雨天時負荷の変動

響は軽微であったといえる，ただし，調査期間内には CSO排水量が1桁大きい降雨イベントも複数回発生して おり（図-3参照），その場合には雨天時負荷は物質収 支に無視できない影響を及ぼしているものと考えられる.

\section{（3）河川水質に及ぼす雨天時負荷の短期的影響}

河川水とCSOの栄養塩濃度および雨天時負荷量の時系 列を図-7に示す．まず，CSO と河川水の溶存無機態窒素 DIN（= $\mathrm{NH}_{4}-\mathrm{N}+\mathrm{NO}_{2}-\mathrm{N}+\mathrm{NO}_{3}-\mathrm{N} ）$ の濃度を比較すると， $\mathrm{CSO}$ の濃度は河川水と同程度あるいはそれ以下であった ことから, $\mathrm{CSO}$ 水塊の流入は河川水濃度を上昇させない

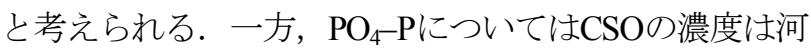
川水よりも常に高く, 最大で3倍近くの值を示しており， $\mathrm{CSO}$ 水塊の流入は河川水濃度を上昇させると考えられる。 実際，CSO負荷量と河川水質の変動についてみると,

CSOの流入が局所的であるために全ての地点ではないが, 採水地点の近くにCSO吐き口が存在するSta.4とSta.6では, $\mathrm{CSO}$ 発生時に河川水の水質濃度が急変したことが確認で きる. 特にSta.6では, $\mathrm{PO}_{4}-\mathrm{P}$ 濃度がCSO発生前の約2倍 に上昇しており，CSOが河川水質を短時間に大きく変化 させていることがわかる．また，CSO発生から約24時間 後においても河川水質濃度はCSO発生前よりも高い值を 示しており，閉鎖性の強い当水域ではCSOが河川水質に 及ぼす影響は比較的長時間にわたることがわかった。

一方, 周辺に吐き口が少ない Sta.1 S Sta.3の濃度変化に ついては，2014年3月13日の調査データが欠損のため検 討できなかった。しかしながら，2013年11月25日に実施 した雨天時調查の結果では, CSO発生前後にSta.1〜Sta.3 における河川水質にほとんど変化が認められなかったこ とから，河川水質に及ぼすCSOの短期的な影響は，吐き 口が集中寸る水域に限定的であると考えられた.

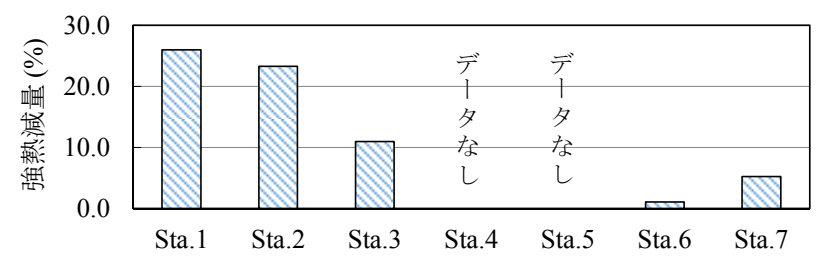

図-8＼cjkstart河床堆積物の強熱減量分布

\section{（4）河道部におけるCSO水塊の滞留日数}

調査期間中に発生した全CSO イベントを対象に，CSO 水塊の河道内滞留日数を算定した. 2. (1)で述べたよう に，上下流端を水門で閉じられた当水域では水位制御お よび潮時に応じた水質浄化運転が行われており，河道部 に流入したCSO水塊は下流端の水門から徐々に排出され る. 東横堀川上流部にもCSO吐き口が存在することを踏 まえて，ここでは下流水門からの排水量の積算值が， $\mathrm{CSO}$ 発生前に上下流水門間に存在した河川水体積と等し くなるまでの日数を滞留日数と定義した. 排水量は, 実 際の水門操作記録を基に，河道部の流表面積と水門操作 前後における河川内の水位変化より算定した. なお，水 門操作の頻度は降雨履歴や月齢などによって変更される ため, 滞留日数はCSOの発生時期によって異なることが 予想される.

算定の結果, CSO水塊の滞留日数は6〜26日とイベン トによって大きく異なり, 平均すると14日であった. 滞 留日数が比較的長期間であること，また上述のように $\mathrm{CSO}$ 水塊の流入が河川水の栄養塩濃度を上昇させること を考慮すると, CSOの発生は河道部における内部生産の 促進に寄与しているものと推察される. 以上のことから， 当水域のような閉鎖性の強い都市河川では, CSO流出抑 制の方策は水質污濁改善に一定の効果を有すると考えら れ，その定量的な評価が今後重要な課題である.

\section{（5）堆積有機物の起源解析}

図-8に河床堆積物の強熱減量の分布を示寸. Sta.4 Sta.5ではデータが久損しているが，これは堆積物中の泥 質が極めて少なく, 強熱減量を測定するのに十分な試料 量を採取できなかったためである. 東横堀川では強熱減 量は $5 \%$ 以下と小さく, 有機物の堆積量は比較的少な かった，一方，道頓堀川では下流に向かうにつれて強熱 減量は増加し, Sta.1 とSta.2では20\%以上の高い值を示し た. 津久井ら ${ }^{8}$ は強熱減量とDO消費量には正の相関があ ることを報告しており，今回下流域で確認された強熱減 量の高い底泥による酸素消費は, 当水域における貧酸素 化要因の一つであると推察される。 また, 入江ら ${ }^{9}$ は道 頓堀川では下流水門からの塩水流入が底質内の還元的反 応を生起し，酸素消費がもたらされることを指摘してい る. 今後, 当水域における貧酸素化機構を解明するため には，塩水流入の影響も含め，水 - 底泥間の相互作用を 


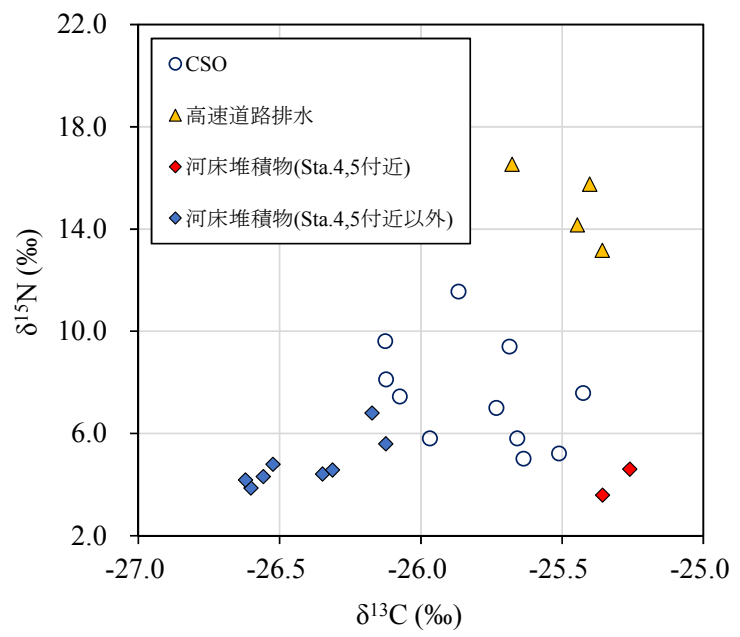

図-9 各試料の炭素 · 窒素安定同位体比

明らかにすることが必要と考える.

CSOおよび高速道路排水中の懸濁物質と河床堆積物に ついて, 安定同位体比の分析結果を図-91に示寸。この $\mathrm{CSO}$ 試料は2014年3月13日の排水開始から終了までに複 数回採取したものであるが，同一のCSOイベント内にお いても， $\delta^{13} \mathrm{C} と \delta^{15} \mathrm{~N} の$ 值にはそれぞれー25.4〜-26.2\%, $5.0 \sim 12.0 \%$ と大きな変動がみられた. 安定同位体比と $\mathrm{CSO}$ 越流量やCSO中の懸濁態物質濃度の関係を調べたと ころ，これらの指標間に明瞭な関係は認められなかった。 河床堆積物の安定同位体比についてみると, 堆積物が 砂質であったSta.4およびSta.5付近の地点とそれ以外の地 点において明確な差異がみられた。しかし， $\delta^{13} \mathrm{C} と \delta^{15} \mathrm{~N}$ の分析精度がそれぞれ $0.1 \%$ ， $\pm 0.15 \%$ であることを考え ると，いずれの地点についても河床堆積物の安定同位体 比組成はCSO試料や高速道路排水試料とは明らかに異 なっており, 河床堆積物の大部分は雨天時負荷以外に由 来していることが示唆された. 河床堆積物の起源として は, 雨天時負荷の他に, 河道部で発生した内部生産起源 有機物や上下流水門外から流入する異地性有機物などが 考えられる. 今後, これらの有機物についても同位体組 成を調べるとともに，試料の粒度分布に関する情報もあ わせて解析することで，より詳細な起源解析を行う予定 である.

\section{4. おわりに}

本研究では，道頓堀川および東横堀川を対象に，雨天 時污濁負荷の実態調査を行うとともに，河川の水質と底 質に及ぼす影響について解析を行った。本研究で得られ た主たる結論は以下の通りである。

1) $\mathrm{CSO}$ と高速道路排水の水質濃度は, 今回の調査デー タからは特定できない要因による影響はあるものの,
概わ降雨状況に忘じて変動することがわかった.

2） 2014年3月13日に発生した中規模の降雨イベントでは, $\mathrm{CSO}$ と高速道路排水による流入負荷量は降雨前の河 川水中存在量の $10 \%$ 以下にとどまり，河道部の物質 収支に及ぼす影響は軽微であると考えられた。

3) 雨天時負荷が河川水質に及ぼす短期的な影響は, CSO吐き口周辺に限定的であるが，地点によっては 河川水の $\mathrm{PO}_{4}-\mathrm{P}$ 濃度を負荷流入前の約 2 倍に上昇させ るなど，無視できないものであった。 また河道部に 排出されたCSO水塊は比較的長期にわたって滞留し, 内部生産の促進に寄与していることが推察された.

4) 道頓堀川下流における河床堆積物の強熱減量は $20 \%$ 以上と高い值を示し，底泥による酸素消費が貧酸素 化要因の一つであると推察された.

5) 河床堆積物の安定同位体比組成は, CSOおよび高速 道路排水中に含まれる懸濁物質とは明らかに異なる ことがわかった。

謝辞 : 現地調査を実施するにあたり，大阪市および(一 財) 都市技術センターの方々には多大なご協力を賜りま した. また, 本研究の一部は (公社) 日本下水道協会, (公財) 大林財団, (公財) 鴻池奨学財団から助成を受けて 実施しました.ここに深く感謝の意を表します。

\section{参考文献}

1) 草場大作, 竹谷究, 藤田昌一, 姫野修司, 小松俊哉 : 合流式下水道越流水の長期観測と流出解析による污濁 負荷の定量的評価, 水環境学会誌, Vol.33, No.5, pp.41-47, 2010.

2) 金子真，二瓶泰雄 : 雨天時越流下水負荷による都市河 川感潮域の大規模貧酸素水塊形成過程, 土木学会論文 集 B1 (水工学), Vol.68, No.4, pp.I_1591-I_1596, 2012. 3) 鯉㴊幸生, 小野澤恵一, 中村格之, 原本英二, 片山浩 之, 古米弘明, 佐藤㥀司, 岡安章夫, 磯部雅彦: 東京 湾お台場海浜公園における雨天時合流式下水道越流水 の影響調查, 海岸工学論文集, Vol.52, pp.886-890, 2005.

4) 西田修三, 中谷祐介, 根井大輝 : 都市感潮河川に流入 する合流式下水道越流水の挙動特性, 土木学会論文集 B1 (水工学), Vol.70, No.4, pp.I_1237-I_1242, 2014.

5) 吉田達朗 : 下水道雨水吐き口からの東横堀川・道頓堀 川 の雨天時排出污濁負荷量測定結果, 下水道業務論 文集, No.26, pp.112-119, 2007.

6) 新矢将尚, 小西孝明, 宮西弘樹, 石川宗孝: 高速道路 排水における污濁負荷の流出特性, 用水之廃水, Vol.44, No.3, pp.207-213, 2002.

7) 日本道路協会: 道路土工要綱平成 21 年度版, 2009.

8) 津久井公昭, 山崎正夫 : 河川底質の評価について (その 3), 東京都環境科学研究所年報, pp.137-142, 1995.

9) 入江政安, 西田修三: 道頓堀川の水質変動特性と水質 管理についての調查解析, 水工学論文集, Vol.51, pp.1129-1134, 2007.

(2014. 9. 30受付) 